\title{
Erratum to: Lateral resolution of nanoscaled images delivered by surface-analytical instruments: application of the BAM-L200 certified reference material and related ISO standards
}

\author{
M. Senoner • A. Maaßdorf • H. Rooch • W. Österle • \\ M. Malcher • M. Schmidt • F. Kollmer • D. Paul • \\ V.-D. Hodoroaba $\cdot$ S. Rades $\cdot$ W. E. S. Unger
}

Received: 16 January 2015 / Accepted: 16 January 2015 / Published online: 21 February 2015

(C) Springer-Verlag Berlin Heidelberg 2015

\section{Erratum to: Analytical and Bioanalytical Chemistry DOI 10.1007/s00216-014-8135-7}

Unfortunately one reference (number 14 in the new list of references, see below) was absent in the published list of references. The citation of this missing ref. 14 in the published text (page 4, left column) is correct. Beginning on page 4 , second column, last paragraph, the numbers of all references are wrong and must be corrected by adding one. In the following text this correction has been done:

Published in the topical collection Reference Materials for Chemical Analysis with guest editors Hendrik Emons and Stephen A. Wise.

The online version of the original article can be found at http://dx.doi.org/ 10.1007/s00216-014-8135-7.

M. Senoner $\cdot$ H. Rooch $\cdot$ W. Österle $\cdot$ V.-D. Hodoroaba $\cdot$ S. Rades $•$

W. E. S. Unger $(\bowtie)$

BAM Bundesanstalt für Materialforschung und -prüfung,

12200 Berlin, Germany

e-mail: wolfgang.unger@bam.de

A. Maaßdorf

Ferdinand-Braun-Institut, Leibniz-Institut für

Höchstfrequenztechntik (FBH), 12489 Berlin, Germany

M. Malcher $\cdot$ M. Schmidt

Fachgebiet Mikro- und Feingeräte, Institut für Werkzeugmaschinen und Fabrikbetrieb, Technische Universität Berlin,

10587 Berlin, Germany

F. Kollmer

ION-TOF GmbH, 48149 Münster, Germany

D. Paul

Physical Electronics Inc., Chanhassen, MN 55317, USA
"Another analytical method able of mapping elemental composition is energy dispersive X-ray spectroscopy (EDX) at a SEM (scanning electron microscope). In the traditional "reflection" geometry and with bulk samples the spatial resolution is limited by the volume of interaction of the primary electrons with the atoms in the sample. This is the volume where the detected X-ray photons originate from and is typically in the range of roughly $1 \mu \mathrm{m}^{3}$. However, recently, it has been demonstrated that SEM working in the transmission mode (TSEM) enables traceable determination of nanoparticle size distribution $[23,24]$. Coupling EDX to TSEM and employing thin electron transparent samples, e.g. FIB lamellae, prepared on TEM grids, results in a significant improvement of the spatial resolution in EDX element maps from the micrometer range down to well below $100 \mathrm{~nm}$ [25]. The limiting factor, however, is the low Xray signal intensity emitted by the tiny amount of material in the lamellae. Recently developed large-area EDS detectors, however, deliver sufficient sensitivity to overcome the problem. The spatial resolution attained practically by EDX in combination with high-resolution TSEM mode can be determined by using a BAM-L200 lamella. An example of a linescan of the $\mathrm{Al}-\mathrm{K} \alpha$ intensity across the gratings P11, P12, P13 and P14 of the BAM-L200 pattern acquired with a modern large-area EDS detector $\left(100 \mathrm{~mm}^{2}\right.$ active area) in the TSEM mode is shown in Fig. 4. Note that the P11 grating (period $42 \mathrm{~nm}$ ) is clearly resolved. Moreover, the presence of the weak $\mathrm{Al} \mathrm{K} \alpha$ signal in the EDX linescan across the narrow stripe W11 (3.5 nm width) is remarkable. Further improvements of the signal to noise ratio by using more sensitive detectors may lead to significantly better results in the near future. The EDX line profile presented in Fig. 4 represents only a single linescan and was not extracted from the full data set of a hypermap. The latter option is available for SEM/EDX, too, but stability issues are often a critical 
point at such high magnifications required to resolve features at the low nm scale.

Possible fine artifacts such as an eccentricity of the profile of the primary electron beam at the low nanometer scale range may occur but control on this problem can be reached readily by rotating BAM-L200 in a way which is analogues to that displayed for the SIMS case in Fig.1.

A traceable calibration of the magnification established in the TSEM images is also enabled by using a BAM-L200 lamella.

Intentionally the BAM-L200 CRM has been designed as a test sample for instruments which use a beam of primary ions, electrons or photons. Nevertheless applications in the field of scanning probe microscopy are possible, too. One example is the imaging of BAM-L200 by Kelvin probe force microscopy where lateral resolutions of better than $30 \mathrm{~nm} \mathrm{[26]} \mathrm{and} 10 \mathrm{~nm}$ [27], respectively, have been demonstrated."

The corrected list of references is as follows:

\section{References}

1. Abbe E (1873) Arch Mikrosk Anat IX:412-468

2. ISO 22493:2008, Microbeam analysis-Scanning electron microscopy-Vocabulary.

3. ISO/TR 19319:2013, Surface chemical analysis- Fundamental approaches to determination of lateral resolution and sharpness in beam-based methods

4. Senoner M, Unger WES (2013) Surf Interface Anal 45:1313-1316

5. Senoner M, Wirth T, Unger WES (2010) J Anal At Spectrom 25: $1440-1452$

6. ISO 18516:2006, Surface chemical analysis - Auger electron spectroscopy and X-ray photoelectron spectroscopy - Determination of lateral resolution to be replaced by ISO 18516:2015, Surface chemical analysis - Determination of lateral resolution and sharpness in beam based methods.

7. Senoner M, Wirth T, Unger WES, Österle W, Kaiander I, Sellin R, Bimberg D (2004) Surf Interface Anal 36:1423-1426

8. Senoner M, Unger WES (2007) Surf Interface Anal 39:16-25

9. BAM-L200 certificate http://www.rm-certificates.bam.de/de/ rmcertificates media/rm cert layer and surface/bam 1200e.pdf
10. Senoner M, Unger WES (2012) J Anal At Spectrom 27(7):10501068. doi:10.1039/c2ja30015j

11. Whitby JA, Östlund F, Horvath P, Gabureac M, Riesterer J, Utke I, Hohl M, Sedláček L, Jiruše J, Friedli V, Bechelany M, Michler J (2012) Adv. in Materials Sci Eng, Article ID 180437, 13 pages. doi:10.1155/2012/180437

12. Kollmer F, Paul W, Krehl M, Niehuis E (2013) Surf Interface Anal 45 (1):312-314. doi:10.1002/sia.5093

13. Holzlechner G, Kubicek M, Hutter H, Fleig J (2013) J Anal At Spectrom 28:1080-1089. doi:10.1039/c3ja50059d

14. Kubicek M, Holzlechner G, Opitz AK, Larisegger S, Hutter H, Fleig J (2014) Appl Surf Sci 289:407-416

15. Alberts D, von Werra L, Oestlund F, Rohner U, Hohl M, Michler J, Whitby JA (2014) Instrumentation Sci Technol 42(4):432-445. doi: 10.1080/10739149.2013.878843

16. Raman SN, Paul DF, Hammond JS, Bomben KD (2011) Microscopy today 19(3):12-15. doi:10.1017/S1551929511000083

17. Yadav P, Bouttemy M, Martinez E, Vigneron J, Renault O, Mur P, Munoz D, Etcheberry A, Chabli A (2011) Frontiers of Characterization and Metrology for Nanoelectronics. AIP Conf Proc 1395:113-117. doi:10.1063/1.3657875

18. Martinez E, Yadav P, Bouttemy M, Renault O, Borowik Ł, Bertin F, Etcheberry A, Chabli A (2013) S J Electron Spectrosc Rela Phenom 191:86-91. doi:10.1016/j.elspec.2013.11.008

19. Senoner M, Wirth T, Unger W, Escher M, Weber N, Funnemann D, Krömker B (2005) J Surface Analysis 12:78-82

20. Bailly A, Renault O, Barrett N, Desrues T, Mariolle D, Zagone LF, Escher M (2009) J. Phys.: Condens. Matter 21, 314002 (7pp)

21. Vila-Comamala J, Jefimovs K, Raabe J, Pilvi T, Fink RH, Senoner M, Maaßdorf A, Ritala M, David C (2009) Ultramicroscopy 109:1360 1364. doi:10.1016/j.ultramic.2009.07.005

22. Keskinbora K, Grévent C, Bechtel M, Weigand M, Goering E, Nadzeyka A, Peto L, Rehbein S, Schneider G, Follath R, VilaComamala J, Yan H, Schütz G (2013) Optics express 11755. doi: 10.1364/OE.21.011747

23. Buhr E, Sanftleben N, Klein T, Bergmann D, Gnieser D, Frase C G, Bosse H (2009) Meas. Sci. Technol. 20: 084025 (9 pp)

24. Hodoroaba V-D, Motzkus C, Macé T, Vaslin-Reimann S (2014) Microsc Microanal 20:602-612. doi:10.1017/S1431927614000014

25. Hodoroaba V-D, Rades S, Unger W E S, (2014) Surf. Interface Anal., published online. doi: 10.1002/sia.5426

26. Machleidt T, Sparrer E, Kapusi D, Franke K-H (2009) Meas. Sci. Technol. 20: 084017. (6pp) doi:10.1088/0957-0233/20/8/084017

27. Cuenat A, Muñiz-Piniella A, Muñoz-Rojo M, Tsoi WC, Murphy CE (2012) Nanotechnology 23: 045703 (7pp). doi:10.1088/0957-4484/ 23/4/045703 